\author{
EWA SOLARCZYK-AMBROZIK \\ Uniwersytet im. Adama Mickiewicza
}

$w$ Poznaniu

\title{
NOWE TRENDY W TEORIACH ROZWOJU KARIER - IMPLIKACJE DLA PORADNICTWA KARIERY
}

\begin{abstract}
Solarczyk-Ambrozik Ewa, Nowe trendy w teoriach rozwoju karier - implikacje dla poradnictwa kariery [New Trends in Career Development Theories: Implications for Career Counselling]. Studia Edukacyjne nr 35, 2015, Poznań 2015, pp. 21-53. Adam Mickiewicz University Press. ISBN 978-83232-2904-9. ISSN 1233-6688. DOI: 10.14746/se.2015.35.2

The article is concerned with transformations of career models, their theoretical explications as well as social methods aimed at solving problems in this area, becoming part of career counselling and mentioned in terms of broader transformations, mainly changes in the sphere of work and the postmodern vision of the world. Detailed analyses deal with new trends in career development theories and they were conducted on the basis of the review of dominant career theories and their implications for counselling methods. Paradigm shifts have been presented, from dominant quantitative approaches to a feature and a factor up to constructivist approaches, thus illustrating new conceptualizations of work life and paradigm shifts in the field of career counselling. Detailed problems shown in the article concern mainly the cultural accuracy of the career counselling theory and methods, the necessity for diversification of research methods concerning careers and their development determinants, integration and convergence of various career theories or diversification of counselling methods.
\end{abstract}

Key words: career development theories, convergence of career theories, career planning, career counselling, paradigm shift, career models, counselling theory and methods indigeneity, culturally sensitive methods

W artykule podjęto problem przeobrażeń zarówno wzorów przebiegu karier, jak i ich teoretycznych eksplikacji, a także zmian praktyk społecznych nastawionych na rozwiązywanie rysujących się w tym obszarze wyzwań, wpisujących się $\mathrm{w}$ nurt poradnictwa kariery, ujmowanych w tle szerszych przeobrażeń, głównie zmian w sferze pracy i ponowoczesnej wizji świata. 
Szczegółowe analizy dokonane w oparciu o przegląd dominujących teorii dotyczą nowych trendów w teoriach rozwoju kariery oraz ich implikacji dla praktyki poradniczej. Ukazane zostały przesunięcia paradygmatyczne - od dominujących ilościowych podejść cechy i czynnika w kierunku podejść konstruktywistycznych, co ilustruje nowe konceptualizacje dotyczące życia zawodowego i zmiany paradygmatyczne w obszarze poradnictwa kariery. Szczegółowe problemy ukazane $\mathrm{w}$ artykule dotyczą między innymi kulturowej adekwatności teorii i praktyki poradnictwa kariery, a także konieczności zróżnicowania metodologii badań w tym obszarze oraz integracji i konwergencji różnych teorii karier czy różnicowania się praktyk poradniczych.

Indywidualizm, refleksyjność i konsumpcjonizm można ukazać jako kategorialne ramy rozważań na temat zmian karier. Refleksję można także usytuować w perspektywie zmian, jakie tworzą dowolność, przypadkowość i nieustrukturyzowanie ludzkich działań. Ideologia indywidualizmu jako logiczne dopełnienie pluralizacji sposobów życia w ponowoczesnej wizji świata ${ }^{1}$, obok innych zjawisk, jak choćby proces "demokratyzacji wiedzy" przejawiający się $\mathrm{w}$ "roszczeniach do bycia uprawomocnionymi, wszelkich sposobów objaśniania świata, jakie znaleźć można na gwałtownie eksplodującym dzięki rozwojowi komunikacji masowej rynku idei"2 to, można przyjąć, obok innych zjawisk, tło przeobrażeń we wzorach przebiegu karier. Jak wskazuje cytowana tutaj autorka, płynność ponowoczesnej rzeczywistości nie likwiduje jednak społecznych ograniczeń i uwarunkowań3, dlatego można kategorycznie stwierdzić, że i one warunkują przebieg współczesnych karier, ale zjawiskiem o zasadniczym znaczeniu - kształtującym podstawowe nurty analizowanych $\mathrm{w}$ niniejszym artykule przeobrażeń zarówno przebiegu karier, ich teoretycznych eksplikacji, jak i praktyk społecznych nastawionych na rozwiązywanie rysujących się w tym obszarze problemów, a do takich zaliczyć można poradnictwo karier - jest fenomen przeobrażeń w sferze pracy. Doradztwo zawodowe w świecie zachodnim na przestrzeni ponad 100 lat swego istnienia rozwinęło szeroki system teorii i strategii interwencyjnych.

Kamieniem milowym $\mathrm{w}$ procesie ewolucji pracy w społeczeństwach zachodnich była rewolucja przemysłowa, w której tle tradycyjna alokacja opar-

\footnotetext{
${ }^{1}$ M. Marody, Jednostka po nowoczesności. Perspektywa socjologiczna, Warszawa 2014, s. 160.

2 Tamże, s. 161.

${ }^{3}$ Tamże, s. 163.
} 
ta na przesłankach klasowych straciła na znaczeniu. Praca stała się środkiem osobistego rozwoju i osiągania pozycji społecznej. W kontekście rewolucji przemysłowej i kultury reformacji zrodziło się pojęcie kariery zawodowej, wyrastającej na jednostkowym zaangażowaniu w pracę, gromadzeniu doświadczenia, przygotowaniu i specjalizacji do całożyciowego jej rozwoju4. Wraz z pojawieniem się nowych zawodów, zjawiła się konieczność łączenia odpowiednich osób z określoną pracą. Przemysł oczekiwał pracowników o sprecyzowanych, mniej lub bardziej zdefiniowanych, kwalifikacjach, umiejętnościach i zdolnościach, zaś pracownicy wyrażali zapotrzebowanie na doradztwo odnośnie pracy, która byłaby dla nich najbardziej odpowiednia, co dało początki doradztwu zawodowemu jako metodzie wspierającej nowy, przemysłowy porządek $\mathrm{w}$ obszarze pracy.

Pomimo iż, historycznie rzecz ujmując, pojęcie kariery zrodziło się $\mathrm{w}$ zachodnim, indywidualistycznym, zindustrializowanym kontekście i na podstawie etyki promującej wolność wyboru, siły globalne przetransponowały je także w inne kulturowo i ekonomicznie lokacje. W świecie globalnej ekonomii jednostki dotykają problemy odnośnie pracy, z których jedne są unikalne dla określonych kontekstów kulturowych, inne zaś wspólne dla wielu grup kulturowych. Rozwój doradztwa zawodowego w "globalną dyscyplinę"5 wymaga ram teoretycznych o uniwersalnej wartości aplikacyjnej, ale również kulturowo specyficznych modeli, wyjaśniających fenomen rozwoju karier na poziomie lokalnym. Indygenizacja teorii stanowiących podstawy doradztwa karier, jak i indygenizacja praktyki winna być zorientowana na identyfikację tak uniwersalnych, jak i unikalnych doświadczeń, konstruktów i praktyk, które są specyficzne dla różnych grup kulturowych ${ }^{6}$.

Jak stwierdza Alurmani, analiza literatury w zakresie rozwoju karier, doradztwa, czy poradnictwa, która rozwinęła się na przestrzeni 60 lat, ujawnia następujące trendy: teorie i modele budowane są głównie na podstawie zachodnich epistemologii, co jest związane z kontekstem ich powstania. Zdaniem cytowanego autora, korzystnym trendem jest pojawienie się kontrowersji, debat dotyczących doskonalenia czy ich adaptacji w inne konteksty, co może wzbogacić praktykę doradztwa. Wiąże się to z odejściem od dominującego podejścia ilościowego cechy i czynnika w kierunku podejść konstruktywistycznych ${ }^{7}$, co można powiedzieć ilustruje pewien przełom paradygmatyczny i nowe konceptualizacje dotyczące życia zawodowego.

\footnotetext{
${ }^{4}$ G. Alurmani i in., The Manifestation of Career, [w:] Handbook of Career Development, International Perspectives, red. G. Alurmani, New York 2014, s. 1.

5 S.A. Leung, The Big Five Career Theories, [w:] International Handbook of Career Guidance, red.

J.A. Athanasou, R. Van Esbroeck, New York 2008, s. 115.

6 Tamże, s. 127.

${ }^{7}$ G. Alurmani i in., The Manifestation of Career, s. 1.
} 
W globalnym świecie znaczącą siłę roboczą stanowią pracownicy w krajach rozwijających się, natomiast poradnictwo kariery realizowane $\mathrm{w}$ środowiskach o odmiennych postawach wobec pracy, czy wzorach karier, oparte jest na definicjach przeniesionych $\mathrm{z}$ innych kultur, co może powodować niską jego skuteczność. Coraz wyraźniej rysuje się potrzeba rdzenności teorii karier dla rozumienia i interpretacji zachowań warunkowanych kulturowo. W literaturze przedmiotu wyraźnie zarysowuje się trend, jakim jest analiza kontekstu, w którym przebiega proces podejmowania decyzji przez jednostkę. Indygeniczny model staje się coraz bardziej popularny jako podejście stosowane dla rozumienia i interpretacji zachowań zachodzących w różnych kontekstach kulturowych, co powoduje dyskusje nad kulturową adekwatnością teorii i praktyki doradczej. „Kulturowa gotowość” jest prezentowana jako konceptualna rama mogąca wzbogacać „kulturowo wrażliwe" (cultural-resonant) interwencje, a dotychczasowy dorobek $\mathrm{w}$ zakresie teorii karier ujmuje się jako istotne źródło konstruowania programów doradztwa dla klientów ze zróżnicowanym dziedzictwem kulturowym ${ }^{8}$.

W świetle dyskusji na temat globalizacji, internacjonalizacji i indygenizacji, odnoszonych również do teorii karier oraz doradztwa czy poradnictwa kariery, podejmuje się krytykę wiodących do tej pory teorii rozwoju karier, wskazując na ich ograniczenia. Zalicza się do nich koncentrację na zmiennych osobowych, z pominięciem zmiennych kontekstowych i kulturowych, rozpatrywanie samorealizacji i satysfakcji z pracy jako celów wyborów zawodowych, podkreślanie znaczenia swobodnego wyboru oraz szans i możliwości w podejmowaniu decyzji, rozwój praktyk i środków zakotwiczonych kulturowo, które trudno adaptować w innych kontekstach9 9

W historii teorii karier nacisk położony był na takie szczegółowe cechy jednostkowe, jak osobowość, zainteresowania, wartości, przekonania, szczegółowo opisywane w tych teoriach (np. w teorii Hollanda), co miało zasadniczy wpływ na powstanie różnorodnych narzędzi diagnostycznych i owocowało redukcjonistycznym postrzeganiem poradnictwa kariery jako procesu określanego mianem "testuj i powiedz"10, na podstawie czego dokonywane były zawodowe predykcje jako rezultat oszacowań, a rozpatrywanie systemu jednostkowego (ujęcie Patton i McMahon) w oderwaniu od szerszego systemu środowiska społecznego, uwarunkowań przestrzennoterytorialnych, statusu społeczno-ekonomicznego czy oddziaływań mediów mogło powodować nieefektywną i nieodpowiednią praktykę doradczą.

\footnotetext{
8 Tamże.

${ }^{9}$ Leung, Yuen, 2012, za: M. McMahon, M. Watson, W. Patton, Context - Resonant Systems. Perspectives in Career Theory, [w:] Handbook of Career Development.

${ }^{10}$ M. McMahon, M. Wattson, W. Patton, Context - Resonant Systems, s. 36.
} 
Od czasu powstania pierwszych teorii kariery podstawę ich tworzył logiczny pozytywizm z jego orientacją na obiektywny pomiar, procedury weryfikacyjne, linearną progresję, wiedzę wolną od wartości, nacisk na fakty - nie uczucia. Założenia natury filozoficznej, długotrwały i dominujący wpływ pozytywizmu ukształtowały dominujące teorie karier ${ }^{11}$.

Prace Parsonsa, Williamsona, Dawisa, czy Lofquista kładą nacisk na wzajemne interakcje zachodzące pomiędzy charakterystykami indywidualnymi i czynnikami tkwiącymi w środowisku pracy. Teoria Supera zapewnia konceptualne ramy dla rozumienia procesu rozwoju kariery w perspektywie cyklu życia, między innymi poprzez umiejscowienie pracy w kontekście ról pełnionych przez jednostkę, wspiera tym samym jednostki $\mathrm{w}$ rozumieniu, artykułowaniu i implementacji ich własnych ról w cyklach życia. Teoria Anny Roe zwraca uwagę na znaczenie wczesnych doświadczeń życiowych dla rozwoju karier, teoria Lindy Gottfredson podkreśla rolę stereotypów związanych z płcią w kształtowaniu aspiracji. Złożona teoria Hollanda zapewnia ramy teoretyczne dla rozumienia i predykcji indywidualnych zachowań. Narzędzia osadzone w tej teorii wspomagają jednostki w identyfikacji i implementacji ich zawodowych tożsamości. Korzystanie z efektywnego oddziaływania określonych wzorów osobowych rozwija zainteresowania i umiejętności prowadzące do satysfakcjonujących wyborów karierowych.

Omawiając problem zmiennej natury karier i wpływu tradycyjnych ich modeli na badania realizowane $\mathrm{w}$ tym obszarze, S.E. Sullivan podkreśla moc eksplanacyjną, jaką badacze łączą z teoriami rozwojowymi. Powołując się na analizy przeprowadzone przez Arthura i Rousseau (1996), pokazuje, iż spośród 58 artykułów opublikowanych w czasopismach, 74\% zakładało jako podstawę ustaleń empirycznych tradycyjny model kariery. Badania głównie opierały się na teoriach Donalda Supera i Daniela Levinsona12. Jak wskazują inni badacze (Hackett i in. ${ }^{13}$ ), teoria Supera znajduje zastosowanie głównie jako wyjaśnienie post hoc uzyskanych ustaleń badawczych, w mniejszym zaś stopniu korzysta się z niej do testowania hipotez dotyczących faz rozwoju zawodowego. Pytania rysujące się $\mathrm{w}$ podejściach krytycznych w odniesieniu do dominujących teorii dotyczą między innymi tego, czy mają one na przykład zastosowanie do wyjaśniania przebiegu karier kobiet oraz czy mają

${ }^{11}$ M. McMahon, New Trends in Theory Development in Career Psychology, [w:] Handbook of Career Development.

12 S.E. Sullivan, The Changing Nature of Careers: A Review and Research Agenda, Journal of Management, 1999, s. 457.

${ }^{13}$ G. Hackett, R.W. Lent, J.H. Greenhaus, Advances in vocational theory and research: A 20 years retrospective, Journal of Vocational Behaviour, 1991, 38. 
nadal równie silną moc aplikacyjną $\mathrm{w}$ dynamicznie zmieniających się warunkach środowiska pracy ${ }^{14}$.

Rewizjonistyczne podejścia do dominujących teorii karier sugerują położenie większego akcentu na zróżnicowane uwarunkowania rozwoju karier, czy formułowanie nowych, mających miejsce w związku ze zmianami społeczno-środowiskowymi, lokalnymi, globalnymi czy też kulturowymi, faz kariery lub cyklów uczenia się i ich inkorporacji do teorii rozwojowych ${ }^{15}$, co pozwoli opisywać i wyjaśniać ten złożony fenomen z uwzględnieniem zróżnicowania siły roboczej, warunków organizacyjnych pracy i dynamicznie zmieniającego się zróżnicowania zawodowego.

Większość teorii wyjaśniających fenomen wyborów karierowych zakła$\mathrm{da}$, że pewne charakterystyki indywidualne i elementy środowiska stwarzają jednostkom możliwości doświadczeń związanych z uczeniem się. Edukacja karierowa staje się przewidywaną trajektorią zadań rozwojowych, realizowanych poprzez kształtowanie umiejętności niezbędnych do rozwijania kariery w różnych organizacjach.

W przeciągu ostatnich dwóch dekad zaprezentowane zostały nowe koncepcje kariery. Mimo dynamicznie zmieniającego się świata pracy i szerszych przeobrażeń środowiskowych, relatywnie długie "panowanie", jak ujmują to McMahon, M. Watson i W. Patton, przypisuje się teorii cechy i czynnika, to jest od początku XX wieku do czasu powstania teorii uwzględniających bardziej rozwojową perspektywę. Założenia tej najwcześniejszej teorii pozostają jednak widoczne w szerokim spektrum teorii mających zastosowanie do dzisiaj, czego przykładem jest teoria konstrukcji kariery Savicasa ${ }^{16}$.

Analiza literatury pozwala stwierdzić wyraźną artykulację potrzeb odnoszących się do bardziej holistycznych i kontekstualnie ukierunkowanych teorii karier, swoistego przejścia od teorii zorientowanych na jednostkę, ujmowaną bez szerszych odniesień kontekstowych, po teorie $\mathrm{z}$ dużym naciskiem uwzględniające kontekstowe uwarunkowania karier jednostkowych. W tych ujęciach poradnictwo karier staje się procesem wzmacniania jednostek w identyfikacji, rozumieniu i adaptacji do systemowych oddziaływań na przebieg ich kariery ${ }^{17}$.

Nowe trendy w obszarze teorii rozwoju karier jawią się oparte na konstruktywizmie i społecznym konstrukcjonizmie. Teorie te odnoszą się do

14 S.E. Sullivan, The Changing Nature of Careers, s. 460.

15 D.T. Hall, P.H. Mirvis, The new protean career: Psychological success and the path with a heart, [w:] The career is dead - long live the career, red. D.T. Hall, San Francisco 1996, s. 15-45.

${ }^{16}$ M. McMahon, M. Watson, W. Patton, Context - Resonant Systems, s. 29.

17 Tamże, s. 30. 
podmiotowości, sprawczości jednostki, nadawania znaczeń, wzajemnych związków zachodzących pomiędzy jednostką a środowiskiem. Zarówno teorie wyrosłe na gruncie pozytywizmu, jak i bazujące na konstruktywizmie wnoszą wiele do psychologii karier, tworząc różnorodne i wartościowe podstawy dla doradztwa karier ${ }^{18}$.

Pionierskie prace Parsonsa odnoszące się do pomocy jednostkom w podejmowaniu decyzji karierowych dały, jak wiadomo, podstawy do rozwoju teorii karier oraz zapładniały podejście cechy i czynnika, z pomiarem i interpretacją, odzwierciedlające się w praktyce doradczej, co owocuje także do chwili obecnej. Stosowanie narzędzi diagnostycznych w praktyce doradczej stanowi podstawowy trend $w$ historii rozwoju karier, co jednak spotyka się z wyraźną krytyką, głównie w zakresie kulturowych korzeni tych narzędzi ${ }^{19}$.

Drugim dominującym trendem w psychologii karier jest to, jak wskazuje McMahon, że od czasu Parsonsa w małym stopniu uwzględnia się w niej wartości „społecznej sprawiedliwości”. Z tego względu między innymi ten obszar psychologii krytykowany jest za jego wyraźną orientację na wartości klasy średniej, bowiem do niej odnoszą się teorie karier ${ }^{20}$. Orientacja na zachodnią klasę średnią powoduje, iż nie uwzględnia się w wystarczającym stopniu na przykład problematyki karier kobiet czy mniejszości etnicznych i w związku z tym ten nurt psychologii nie może mieć szerokiego zastosowania $w$ innych kontekstach kulturowych. Krytycy takich orientacji w psychologii karier zwracają uwagę na niedocenianie $w$ teoriach wpływu na przebieg indywidualnych karier takich czynników, jak: płeć, pozycja społeczna, kontekst środowiskowy, uwarunkowania rodzinne, czy charakterystyki kulturowe, sugerując równocześnie zwiększenie zainteresowania problematyką bezrobocia i ubóstwa ${ }^{21}$.

Inne sugestie dotyczące teorii karier wskazują na konieczność mniejszej koncentracji na indywidualistycznym, redukcjonistycznym i pozytywistycznym ogniskowaniu badań oraz praktyki poradniczej i w większym stopniu uwzględnianiu problemu nierówności społecznych, z odniesieniem do wartości sprawiedliwości społecznej oraz znaczenia środowiska lokalnego ${ }^{22}$.

Tradycyjne teorie karier, krytykowane jako w zbyt wąskiej perspektywie ujmujące rozwój jednostek, w ich zrewidowanych artykulacjach uwzględniają elementy szerszego systemu, czego przykładem są prace Supera. Za-

${ }_{18}$ M. McMahon, New Trends in Theory Development in Career Psychology.

19 Tamże.

20 Tamże, s. 15.

${ }^{21}$ D.L. Blustein, Vocational Psychology at the fork in the Road: Staying the course or taking the road less traveled, Journal of Career Assessment, 2011, 19.

22 Stead, Perry, 2012, za: M. McMahon, New Trends in Theory Development in Career Psychology. 
równo w badaniach, jak i w praktyce poradniczej oczekuje się, że teoretyczne podstawy tej działalności będą odnosić się do takich elementów systemu społecznego, jak rodzina, grupy społeczne, czy uwarunkowania przestrzenno-terytorialne, warunki społeczno-ekonomiczne, procesy globalizacji itp. ${ }^{23}$

Znaczące nurty krytyki psychologii karier dotyczą braku konsensusu w zakresie podstawowych terminów i definicji. Terminy takie, jak rozwój karier, psychologia karier, doradztwo zawodowe, poradnictwo karier mają szerokie zastosowanie ${ }^{24}$.

Brak konceptualnej klarowności stanowi jeden z podstawowych nurtów krytyki. Od czasu Parsonsa (1909) takie pojęcia, jak kariera, zawód, praca zawodowa używane były jako synonimy, chociaż D.S. Miller i Mc Whirter (2006) stwierdzają, że współczesne analizy przedmiotu wyraźnie różnicują rozumienie pojęć: praca, zawód, kariera ${ }^{25}$. Tradycyjne ujęcia kariery są krytykowane za restrykcyjne jej ograniczenia do życia zawodowego i uwzględnianie $\mathrm{w}$ rozwoju kariery linearnego progresu, natomiast nowe ujęcia proponują poszerzenie tych ujęć o odniesienia do życia przedzawodowego i pozawodowego oraz innych ról i kontekstów życiowych.

Warto jeszcze raz podkreślić, że krytyczne analizy ujęć pojęciowych i kategorialnych zwracają uwagę na orientację na zachodnią klasę średnią i niską wartość aplikacyjną w innych niż zachodni kontekstach kulturowych. W tradycyjnych ujęciach kariera odnosi się do sekwencji „zatrudnieńn” na przestrzeni biegu życia jednostki i w społeczeństwach zachodnich przybiera postać wertykalnego zawansowania $\mathrm{w}$ pracy, łączonego z doświadczeniem, a nie tylko z formalnym awansem. Patton i McMahon zwracają uwagę na propozycje niektórych autorów dotyczące neutralnego, ich zdaniem, terminu, jakim są "historie pracy” denotujące sekwencje doświadczenia zdobytego podczas wykonywania pracy i wypełnienie treścią pojęcia kariery poprzez nadawanie mu znaczeń przez jednostkę, będące indywidualną ekspresją tożsamości ${ }^{26}$. Znacząca zmiana $\mathrm{w}$ literaturze przedmiotu dotyczy wyeksponowania roli jednostek $\mathrm{w}$ nadawaniu znaczenia pojęciu kariery. W takim ujęciu kariera staje się konstrukcją subiektywną, a nie czymś istniejącym obiektywnie, niejako do zdobycia. Z takim podejściem dyskutują Patton, Watson i McMahon, postrzegając jednostkowe kariery jako rozwijane

${ }^{23}$ M. McMahon, M. Watson, W. Patton, Context - Resonant Systems, s. 31.

${ }^{24}$ M. McMahon, New Trends in Theory Development in Career Psychology.

${ }^{25}$ W. Patton, M. McMahon, Career Development and Systems Theory. Connecting Theory and Practice (3rd ed.), Rotterdam-Boston 2014, s. 4.

${ }^{26}$ Nicholson, West 1989, za: W. Patton, M. McMahon, Career Development and Systems Theory, s. 5. 
przez jednostki, ale na bazie ich działań i postaw wobec kariery ${ }^{27}$. Ten nurt refleksji odzwierciedla także rozróżnienie przez Savicasa kariery w sensie obiektywnym i w sensie subiektywnym ${ }^{28}$.

Zarysowuje się orientacja w kierunku integracji i konwergencji różnych teorii karier, co sprzyjać ma w założeniach także jakości poradnictwa karier, bowiem osiągnięcia konstruktywizmu, teorii systemu, teorii działań, jak wskazują niektórzy autorzy ${ }^{29}$, pozwalają na wielowymiarowe odniesienia do procesu rozwoju jednostki w różnych okresach jej życia. W ocenie Kidd, podejmowane na przestrzeni lat próby porównań i integracji teorii z odniesieniami do poradnictwa kariery przybierały postać hybrydowych, eklektycznych lub integracyjnych ujęćc ${ }^{30}$.

Krytyka psychologii karier dotyka także problemu jej izolacji jako dyscypliny naukowej. Wzbogacenie podstaw teoretycznych $\mathrm{w}$ obszarze problematyki karier mogłaby mieć miejsce w wyniku większej współpracy między takimi dyscyplinami, jak socjologia, organizacja i zarządzanie czy studia edukacyjne. Jako efekt tej współpracy Gunz i Peiperl (2007) proponują wyodrębnienie studiów karierowych ${ }^{31}$.

W nurcie krytycznym znajduje odzwierciedlenie również problem konieczności zróżnicowania metodologii badań w obszarze karier. Zwraca się uwagę na znacznie rzadsze stosowanie podejść jakościowych niż ilościowych. McMahon, cytując Steada i in. (2012), którzy dokonali analizy zawartości artykułów publikowanych w 11 czasopismach w latach 1990-2009, pokazuje, że tylko 6,3\% z 3279 artykułów opartych było na wynikach badań z zastosowaniem podejścia jakościowego ${ }^{32}$.

Obszerny system teorii rozwoju karier i strategii interwencyjnych w tradycyjnym i dominującym ujęciu ma bogate opracowania literaturowe. S.A. Leung wymienia pięć teorii, które na przestrzeni kilku ostatnich dekad zdominowały zarówno badania, jak i poradnictwo karier. Są nimi: Teoria dostosowania zawodowego (TWA) Davisa i Lofquista; Teoria wyboru zawodu J.L. Hollanda; Teoria rozwoju zawodowego Supera i zrekonceptualizowana jej wersja, jaką jest Teoria konstrukcji kariery M.L. Savickasa; Teoria ograniczeń i kompromisów L.S. Gottfredson oraz społeczno-poznawcza

27 W. Patton, M. McMahon, Career Development and Systems Theory.

${ }^{28}$ M.L. Savicas, Career construction: A developmental theory of vocational behavior, [w:] Career choice and development (4th ed.), red. D. Brown i in., San Francisco 2002, s. 152.

${ }^{29}$ M. McMahon, M. Watson, W. Patton, Context - Resonant Systems.

30 J.M. Kidd, Understanding Career Counselling. Theory, Research and Practice, 2006.

${ }^{31}$ Gunz i Peiperl 2007, za: M. McMahon, New Trends in Theory Development in Career Psychology, s. 18.

${ }^{32}$ M. McMahon, New Trends in Theory Development in Career Psychology, s. 17. 
Teoria kariery (SCCT) R.W. Lenta ${ }^{33}$. „Wielka Piątka” teorii karier, mimo iż rozwinięta została w USA, służy praktyce poradniczej w wymiarze międzynarodowym i pomimo faktu, że $\mathrm{w}$ jakimś stopniu teorie te są aktualizowane i unowocześniane w odpowiedzi na zachodzące zmiany, nadal są konceptualnie i empirycznie zakotwiczone w społecznym i zawodowym kontekście USA i jak wyraźnie artykułuje to Leung, doradcy opierający swą praktykę na innych przesłankach, w innym niż amerykański kontekście, winni mieć na uwadze konieczność ich modyfikacji i adaptacji do zróżnicowanych warunków. W świecie globalnej ekonomii wszystkie jednostki doświadczają problemów, mających swoje źródło w pracy. Niektóre z tych problemów są unikalne dla określonych obszarów kulturowych, inne zaś, jak na przykład poszukiwanie sensów i znaczeń, życiowa podróż mająca na celu aktualizację siebie poprzez pełnienie różnych ról życiowych i ról odnoszonych do pracy, czy wysiłek podejmowany by rozwiązać problem bezrobocia, jawią się na poziomie globalnym ${ }^{34}$.

Celem niniejszego artykułu nie jest charakterystyka poszczególnych teorii karier, która stanowi temat szczególnie płodny i znajdujący bogactwo opracowań literaturowych, także na gruncie polskim ${ }^{35}$, jednak mając na uwadze wpływ tych teorii na doradztwo zawodowe, czy przy uwzględnieniu przesunięcia paradygmatycznego na poradnictwo kariery, a przede wszystkim ze względu na istotny, $\mathrm{z}$ racji podjętego tematu, problem konwergencji teorii i jego skutków dla praktyki, coraz częściej podnoszony przez różnych badaczy, warto w sposób skrótowy przyjrzeć się ich roli w tym zakresie.

O aplikacyjnej wartości teorii Hollanda mówi się, podkreślając jej ogromny, długotrwały wpływ na praktykę doradczą i inspirowanie badań $\mathrm{w}$ tym zakresie ${ }^{36}$. Podkreśla się jej znaczenie $\mathrm{w}$ badaniach nad strukturą zainteresowań zawodowych, ukazujących równocześnie wartość opartych na niej narzędzi diagnostycznych. Aktualne sugestie dotyczą poddania analizie poprzez procedury badawcze innych, ważnych dla praktyki założeń tej teorii, takich jak między innymi odniesienia do dynamicznie zmieniającego

33 S.A. Leung, The Big Five Career Theories.

${ }^{34}$ Tamże, s. 115.

35 A. Bańka, Psychologiczne doradztwo karier, Poznań 2007; B. Wojtasik, Doradca zawodu. Studium teoretyczne z zakresu poradoznawstwa, Wrocław 1994; J. Minta, Od aktora do autora. Wspieranie młodzieży w konstruowaniu własnej kariery, Warszawa 2012; A. Bilon, Wspótczesne tendencje $w$ badaniach poradnictwa kariery, Studia Poradoznawcze, 2013, s. 42-64; A. Cybal-Michalska, Młodzież akademicka a kariera zawodowa, Kraków 2013.

36 S.A. Leung, The Big Five Career Theories; por. V.G. Zunker, Career Counseling: Applied Concepts of Life Planing, Brookes/Cole - Thomson Learning, 2002. 
się środowiska pracy, predykcyjnej wartości zainteresowań zawodowych czy aplikacyjnej jej wartości w środowisku wielokulturowym, ze swoistymi kodami zawodowymi i edukacyjnymi oraz lokalnymi zasobami ${ }^{37}$.

Spośród wielu teorii karier najpopularniejszą, zarówno w USA, jak i w innych krajach, jest Teoria rozwoju zawodowego Supera, której założeniem jest to, że wybory karierowe i sam rozwój kariery ujmowany jest jako proces rozwoju i implementacji „ja”, będącego produktem złożonych interakcji zachodzących pomiędzy różnego rodzaju czynnikami, między innymi rozwojem fizycznym, psychicznym, doświadczeniami osobowymi oraz różnymi cechami środowiska i jego oddziaływaniem ${ }^{38}$. Warto podkreślić, za Leungiem ${ }^{39}$, że wiele aspektów teorii Supera jest atrakcyjnych dla praktyki poradniczej $\mathrm{w}$ wymiarze międzykulturowym. Są nimi wprowadzone koncepcje zadań rozwojowych, faz rozwoju zawodowego, ról życiowych, czy pojęcie dojrzałości karierowej, choć warto zwrócić uwagę w tym miejscu, że odnośnie tej ostatniej kategorii, w związku ze zmianami we wzorach przebiegu karier pojawiają się sugestie zastąpienia jej koncepcją „adaptacyjności"40. Warto w tym miejscu również zasygnalizować znaczenie koncepcji sformułowanej przez Savicasa, który opierając się na założeniach koncepcji Supera i przyjmując równocześnie perspektywę konstruktywistyczną wskazuje, że proces konstruowania kariery jest zasadniczo rozwojem i implementacją tożsamości zawodowej w role związane z wykonywaniem pracy. Koncepcja Supera oferuje dla praktyki poradniczej obszerne ramy kategorialne służące opisowi i wyjaśnianiu procesu rozwoju zawodowego, dobrze służące przez lata poradniczym interwencjom. Najnowsze zakotwiczenie teorii $\mathrm{w}$ rozwojowym kontekstualizmie ${ }^{41}$ pozwala na uwzględnienie ustaleń ekologii społecznej, dotyczących wzajemnych zależności, jakie zachodzą pomiędzy jednostką a jej środowiskiem, $\mathrm{z}$ równoczesnym uznaniem efektu wpływów subiektywnych, kulturowo zdeterminowanych wartości i przekonań na zawodową tożsamość oraz preferencje zawodowe. W perspektywie interpretacyjnej ekologii społecznej można ująć, że jednostka w celu maksymalizowania samorealizacji i równocześnie społecznej akceptacji negocjuje społecznie akceptowalne rozwiązania oraz opcje i, jak wskazuje Leung, mówiąc o stosowalności różnych teorii karier w określonych kontekstach kulturowych, zarówno decyzje karierowe, jak i rozwój kariery nie sta-

37 S.A. Leung, The Big Five Career Theories.

38 V.G. Zunker, Career Counseling.

${ }^{39}$ S.A. Leung, The Big Five Career Theories.

${ }^{40} \mathrm{~Np}$. E.L. Herr, Super`s life - span, life - space approach and its outlook for refinement, The Career Development Quarterly, 1997, 45, s. 238-245; M.L. Savicas, Career construction.

${ }^{41}$ S.A. Leung, The Big Five Career Theories, s. 121. 
nowią linearnej implementacji koncepcji „ja”, lecz są procesem negocjacji i kompromisów ze środowiskiem ${ }^{42}$.

Do „Wielkiej Piątki” 43 długotrwale oddziałującej na praktykę doradztwa karier zalicza się także teorię dostosowania pracy (TWA), zakotwiczoną $\mathrm{w}$ tradycji indywidualnych różnic zachowań zawodowych, zwaną teorią zgodności jednostka - środowisko, rozwiniętą przez Davisa w 1964 roku i ujmującą wybory karierowe oraz rozwój kariery jako ustawiczny proces dostosowania oraz akomodacji wymagań jednostki i organizacji ${ }^{44}$. Teoria ta, pierwotnie mająca miejsce $w$ studiach nad dopasowaniem: jednostka - praca, znalazła także - wobec założenia, że „praca jest zlokalizowaną w czasie i przestrzeni wersją zawodu" 45 - zastosowanie $w$ warunkach organizacji. Główne jej założenia odzwierciedla hipoteza, że im bardziej jednostkowe cechy (umiejętności, wiedza, doświadczenie, postawy, zachowania) korespondują $\mathrm{z}$ wymaganiami roli zawodowej, tym bardziej prawdopodobne jest dobre, oceniane z perspektywy organizacji, wykonywanie przez jednostkę satysfakcjonującej ją pracy ${ }^{46}$. Poziom satysfakcji jednostki z pracy jest, $\mathrm{w}$ tym ujęciu, predykatorem prawdopodobieństwa trwałości pracy (dłuższego zatrudnienia) $\mathrm{w}$ ramach jednej organizacji i ustawicznego w niej zaawansowania, wyrażanego doświadczeniem zawodowym. Mając na uwadze problem konwergencji teorii, do którego omówienia przejdę $\mathrm{w}$ dalszej części artykułu, zasygnalizować jednak chciałabym w tym miejscu mocną stronę tej teorii (TWA), o której mówi Davis ${ }^{47}$, a którą jest powstały w oparciu o nią szerzej stosowany zespół narzędzi pozwalający na pomiar poziomu satysfakcji z pracy, potrzeb i wartości, czy określenie indeksu odpowiedniości.

Wymienione tutaj, bardzo szkicowo, charakterystyki tej teorii, wobec dynamicznych zmian środowiska pracy, jej charakteru, zmian we wzorach przebiegu karier, czy psychologicznych kontraktów między pracodawcą i pracownikiem oraz $\mathrm{w}$ konsekwencji tych procesów, także zmian paradygmatycznych $w$ obszarze poradnictwa karier, wskazują, jak bardzo teorie sytuujące się $\mathrm{w}$ paradygmacie dopasowania nie odpowiadają potrzebom współczesności.

42 Tamże, s. 122.

43 S.A. Leung, The Big Five Career Theories.

${ }^{44}$ R.V. Davis, The Minnesota theory of work adjustment, [w:] Career Development and Counseling. Putting Theory and Research to Work, red. D. Brown, R.T. Lent, New York 2005.

${ }^{45}$ R.D. Jr. Bretz, T.A. Judge, Person - Organization Fit and the Theory of Work Adjustment: Implications for Satisfaction, Tenure and Career Success, Journal of Vocational Behavior, 1994, 44, s. 32 .

46 Tamże.

${ }^{47}$ R.V. Davis, The Minnesota theory of work adjustment. 
Społeczno-poznawcza Teoria kariery (SCCT) Lenta, Browna i Hacketta48, jako kolejna z „Wielkiej Piątki” dominujących przez lata teorii, zakotwiczona w teorii samoskuteczności Bandury, odnosząca się do wzajemnych relacji zachodzących między jednostką a środowiskiem, wyjaśnia proces kształtowania się zainteresowań zawodowych, proces dokonywania wyborów zawodowych i edukacyjnych, proces realizacji karier i dróg edukacyjnych. Kluczowymi w teorii zmiennymi są: samoskuteczność, oczekiwania rezultatów, definiowane jako ,jednostkowe przekonania na temat konsekwencji czy rezultatów określonych zachowann" 49 , cele osobowe i zainteresowania. SCCT ujmuje rozwój celów i wyborów karierowych jako funkcję interakcji zachodzących pomiędzy poczuciem samoskuteczności, oczekiwaniem rezultatów i zainteresowaniami na przestrzeni czasu. Model zainteresowań określa, że jednostki prawdopodobnie będą rozwijać zainteresowania poprzez te aktywności, które odbierają jako skuteczne i antycypują jako prowadzące do pozytywnych rezultatów. Dynamika interakcji zachodzących pomiędzy zainteresowaniami, poczuciem skuteczności i antycypowanymi rezultatami prowadzi do kształtowania się stabilnych wzorów zainteresowań w dłuższej przestrzeni czasowej $\mathrm{w}$ okresie adolescencji i wczesnej dorosłości.

Leung eksponując niewątpliwą wartość SCCT dla praktyki doradczej, mówi o konieczności dalszego testowania ujętych w niej hipotez oraz dalszego rozwoju lub adaptacji stosowanych narzędzi diagnostycznych po to, by pomiary $\mathrm{z}$ ich użyciem miały wartość i były wiarygodne $\mathrm{z}$ uwzględnieniem zróżnicowanego kontekstu kulturowego ${ }^{50}$.

$\mathrm{W}$ porównaniu z teoriami omówionymi wcześniej, Teoria ograniczeń i kompromisów Gottfredson jest relatywnie nowa. Wprowadzona została w roku 1981, a jej twórczyni oparła się na założeniach, że wybór ścieżki kariery jest procesem wymagającym wysokiego poziomu sprawności poznawczej, bowiem rozwój poznawczy jest podstawą kształtowania się kognitywnej mapy zawodów i koncepcji "ja”, stanowiąc podstawę ewaluacji odpowiedniości określonych, zawodowych alternatyw. Późniejsze, autorskie rewizje tej teorii rozbudowują założenia dotyczące wzajemnych, dynamicznych relacji pomiędzy wyposażeniem genetycznym jednostki a jej środowiskiem. Gottfredson nie określa wyborów zawodowych jako procesów selekcji, natomiast zakłada, że wybory te i rozwój kariery to proces eliminacji lub ograniczeń, w trakcie którego jednostka progresywnie eliminuje pewne zawodowe alternatywy z obszaru swoich możliwości. W ujęciu tym rozwój

${ }^{48}$ R.W. Lent, S.D. Brown, G.I. Hackett, Social cognitive career theory, [w:] Career choice and development, San Francisco 2002.

49 Tamże, s. 262

50 S.A. Leung, The Big Five Career Theories, s. 127. 
kariery jest postrzegany jako proces kreacji siebie, w którym jednostka poszukuje niszy do wyrażenia swoich genetycznie warunkowanych inklinacji w obszarze zakreślonym granicami jej środowiska ${ }^{51}$. Jak zwraca uwagę Leung, teoria Gottfredson oferuje unikalną perspektywę dla poradnictwa karier $\mathrm{w}$ wymiarze międzynarodowym, co ma swoje uzasadnienie $\mathrm{w}$ argumentacji, iż $w$ wielu kulturach życiowe osiągnięcia mierzone są sukcesem edukacyjnym i pozycją karierową, charakteryzującą się wysokim statusem społecznym i poziomem wpływów. Również stereotypy płciowe stanowią element wielu kultur, w rezultacie czego jednostki są zachęcane do wykonywania zawodów jako odpowiednich do ich płci52, który to aspekt mocno eksponuje teoria Gottfredson.

Teoria ta, jak stwierdza jej twórczyni, dzieli wiele założeń z innymi teoriami i w związku z tym prowadzi do wielu wspólnych $\mathrm{z}$ nimi rekomendacji, lecz równocześnie domaga się „dopasowania starych narzędzi do nowych wyzwań" 53 , by móc odpowiedzieć na takie pytania, jak na przykład: jak można pomóc klientowi zidentyfikować genetycznie warunkowane możliwości i ograniczenia, które trudno zaobserwować bezpośrednio? w jaki sposób można wskazać na realizm zawodowych opcji bez odbierania nadziei i zmniejszania szans? w jaki sposób dostarczyć klientowi informacji nie sprawując nad nim równocześnie władzy?54

Kontynuując nurt refleksji dotyczący wpływu teorii na praktykę w zakresie poradnictwa karier, który w odniesieniu do „Wielkiej Piątki” wyraźnie zarysowuje Leung 55 , można powtórzyć za tym autorem, że teoria Gottfredson może stanowić także konceptualny przewodnik do budowania programów doradztwa w szkołach, a sama jej twórczyni przedstawia model interwencji doradczych składający się ze strategii doradczych i narzędzi, które mogą być stosowane $\mathrm{w}$ celu optymalizacji procesu przyswajania informacji zawodowych, wzmacniania doświadczenia i aktywności, pozwalających dzieciom i adolescentom zrozumieć odnoszone do kariery własne cechy osobowe, konceptualizować przyszłe ścieżki kariery w realistyczny, możliwy do osiągnięcia sposób inwestowania w siebie w celu implementacji preferowanych opcji karierowych. Te szeroko zarysowane strategie mogą być stosowane $\mathrm{w}$ wielu kulturowych kontekstach $\mathrm{z}$ odniesieniem do środowiska szkolnego.

51 Tamże, s. 121.

52 Tamże, s. 124.

53 L.S. Gottfredson, Applying Gottfredson's Theory of Circumscription and Compromise in Career Guidance and Counselling, [w:] Career Development and Counseling, s. 85.

54 Tamże, s. 84

55 S.A. Leung, The Big Five Career Theories. 
„Wielka Piątka” teorii karier oferuje doradcom kariery zbiór ram konceptualnych, w których mogą zakotwiczyć i rozwinąć uprawianą dyscyplinę zarówno lokalnie, jak i globalnie. Istnieje jednak potrzeba, jak wskazują niektórzy badacze, krytycznej ewaluacji tego, jak podstawowe, ujęte $\mathrm{w}$ nich zmienne, takie jak na przykład: dostosowanie do środowiska pracy, zainteresowania, role życiowe, poczucie skuteczności, są interpretowane w zróżnicowanych kontekstach zastosowania tych teorii oraz czy ewaluacji tego, jak wprowadzenie kulturowo specyficznych zmiennych w obszar ram zakreślających przestrzeń rozwoju karier może zwiększyć wszechstronność i moc eksplanacyjną teorii ${ }^{56}$.

Nowe trendy w teoriach rozwoju karier rozpatrywane mogą być jako odpowiedź na zachodzące zmiany i wyzwania współczesnego świata. W wielu dyscyplinach, o czym pisze McMahon ${ }^{57}$, odpowiedzi te kształtowane są przez przyjęte założenia konstruktywizmu i społecznego konstrukcjonizmu, które to założenia, $\mathrm{w}$ większym stopniu niż pozytywistyczny ogląd świata z wąskim, lecz szczegółowym wyjaśnieniem wielu fenomenów, pozwalają odpowiedzieć na wyzwania współczesności, szczególnie na potrzeby poradnictwa kariery w kontekście złożonych oczekiwań klientów.

Nowe wyzwania powodują pojawienie się teorii, które uwzględniają zarówno kategorię szans jako jednego z wielu czynników oddziałujących na proces rozwoju kariery (np. ramowa teoria systemów rozwoju kariery - The Systems Theory Framework of Career Development - STF) czy równocześnie szans i chaosu, nieprzewidywalność, ujmowaną w zde-skonstektualizowanej perspektywie (Teoria chaosu) ${ }^{58}$, po teorie $\mathrm{z}$ dużym naciskiem uwzględniające kontekstowe uwarunkowania jednostkowych karier59.

Warto podkreślić, iż kategoryzacja nowych trendów w teoriach rozwoju karier ma już bogate odniesienia literaturowe i na przykład Mc Mahon ${ }^{60}$ wskazuje na: Teorię działania kontekstowego Younga i in., Teorię konstrukcji kariery Savicasa ${ }^{61}$, Teorię chaosu Brighta i Pryora ${ }^{62}$, Ramową teorię systemów McMahon i Patton (Systems Theory Framework of Career Development), czy Relacyjną teorię pracy (Relational Theory of Working) Blusteina. Autorka ta

56 Tamże.

${ }^{57}$ M. McMahon, New Trends in Theory Development in Career Psychology.

58 R.G.L. Pryor, J.E. Bright, The Chaos Theory of Career: A New Perspective on Working in the Twenty - First Century, New York 2011.

${ }_{59}$ M. McMahon, M. Watson, W. Patton, Context - Resonant Systems. Perspectives in Career Theory, s. 30

${ }^{60}$ M. McMahon, New Trends in Theory Development in Career Psychology, s. 18.

${ }^{61}$ M.L. Savickas, The Theory and practice of career construction, [w:] Career Development and Counseling, s. 42-70.

62 R.G.L. Pryor, J.E. Bright, The Chaos Theory of Career. 
podkreśla, że każda z wymienionych wyżej teorii charakteryzuje się zdolnością dostosowania do złożoności społecznego życia, ponieważ przyjmuje holistyczną, kontekstualną perspektywę rozwoju kariery - wszystkie dotyczą kontekstualnie osadzonej ich natury oraz całokształtu kontekstowo zdeterminowanego procesu rozwoju kariery. Jako wartościowe traktują pojęcie subiektywności karier i jednostkowego doświadczenia kariery, co wzbogaca ich interpretacje o wymiar duchowości, szczególnie istotny dla praktyk spoza zachodniego obszaru kulturowego, ale również zwraca uwagę na wartość obserwowalnego wymiaru kariery $w$ ujęciu obiektywnym ${ }^{63}$.

Te nowe trendy odzwierciedlone $w$ teoriach rozwoju karier mają szczególną wartość aplikacyjną dla praktyki poradniczej. Alurmani mówi tu o „przygotowaniu kulturowym”, podejściu „kulturowej gotowości”, która kontekstualizuje interwencje karierowe $\mathrm{w}$ określonych lokalnych warunkach $^{64}$, a Mc Mahon określa problem jako wrażliwość teorii na powszechność i specyficzność. Jak stwierdza ta autorka, stosowane teorie, realizowane badania i oparta na nich praktyka poradnicza w XX wieku służyły dobrze rozwojowi karier, lecz nie są wystarczające dla strategicznej pozycji karier w globalnym świecie, stąd nowe trendy rozwojowe spełniają oczekiwania wobec bardziej holistycznie zorientowanej interpretacji zjawisk, bliższych związków teorii, badań i praktyki, co w połączeniu z dorobkiem dominujących do tej pory trendów rozwojowych może znacznie wzbogacić psychologię karier65.

Założenia dotyczące wzrastającej złożoności świata, w którym żyje jednostka, znajdują swoje odzwierciedlenie w myśleniu systemowym, wyraźnym $\mathrm{w}$ nowych podejściach $\mathrm{w}$ poradnictwie karier, postrzegających klienta holistycznie, w szerszym kontekście jego życia, takich jak na przykład: podejście aktywnego zaangażowania Amundsona (2009), Cochrana poradnictwo narracyjne (1997), McMahon i Watsona opowiadanie historii życia (2010), Peavy`ego podejście socjodynamiczne (1998), czy Savicasa projektowanie życia (2009) ${ }^{66}$. Doradztwo karier wpisujące się w paradygmat różnic indywidualnych ujmuje klientów jako podmioty, które mogą być charakteryzowane poprzez określenie, odzwierciedlonego na skali nasilenia cech, które $\mathrm{z}$ kolei mogą być łączone $\mathrm{z}$ określoną ofertą zawodową. $\mathrm{W}$ ujęciu tym także edukacja karierowa $\mathrm{w}$ terminach subiektywnego, indywidualnego rozwoju bazuje na charakterystykach stopnia gotowości klienta do zaanga-

${ }^{63}$ M. McMahon, New Trends in Theory Development in Career Psychology, s. 18.

${ }^{64} \mathrm{G}$. Alurmani i in., The Manifestation of Career.

${ }_{65}$ M. McMahon, New Trends in Theory Development in Career Psychology, s. 24.

${ }_{66}$ M. McMahon, M. Watson, W. Patton, Context - Resonant Systems. Perspectives in Career Theory. 
żowania w zadania rozwojowe odpowiednie dla określonych etapów cyklu życia i w związku z tym pomaga mu rozwijać nowe postawy, przekonania i umiejętności. Teorie socjologiczne karier ukazują natomiast, iż decyzje jednostki dotyczące kariery nie są $\mathrm{w}$ tak wielkim stopniu kształtowane głównie przez jej cechy osobowe, lecz mocno zakotwiczone także w jej środowisku. Preferencje dotyczące wyborów zawodowych nie są jedynie funkcją zainteresowań, wartości czy umiejętności, bowiem podlegają uwarunkowaniom społecznej stratyfikacji.

Perspektywy takie, jak konstruktywizm i teoria systemów zakładają, że jednostki aktywnie konstruują swoją rzeczywistość i są zdolne do aktywnego konstruowania znaczących pozycji w kontekście pracy. Projektowanie życia, będące szerszą kategorią pojęciową wpisaną w perspektywę społecznego konstruktywizmu, postrzega klienta jako podmiot charakteryzowany przez jego autobiograficzne narracje, służące, dzięki refleksji nad tematami życia, budowaniu ścieżek kariery ${ }^{67}$.

Wraz ze zmianami społecznymi, ekonomicznymi, indywidualizacją, czego konsekwencją jest przesunięcie w zakresie odpowiedzialności za przebieg kariery, niezbędna jest wiedza do planowania życia czy kształtowania tożsamości zawodowej - wiedza autobiograficzna, możliwa do zdobycia poprzez procesy narracyjne. Inwestycje w kapitał tożsamościowy pomagają $\mathrm{w}$ zmaganiach i rozwiązywaniu problemów jawiących się $\mathrm{w}$ tle tranzycji w obszarze pracy, zmianach zawodu, miejsc pracy, ról zawodowych. Na podstawie tych narracji doradcy ułatwiają klientom budowanie konstruktów dotyczących karier, bez utraty poczucia tożsamości i społecznej identyfikacji ${ }^{6}$. W procesie towarzyszenia klientowi $\mathrm{w}$ planowaniu życia doradcy koncentrują się bardziej na jego tożsamości niż osobowości, adaptacyjności niż dojrzałości, zamierzeniach niż decyzjach, bardziej na narracjach, historiach życia niż osiągniętych na skali punktach ${ }^{69}$. Epistemologiczne założenia dotyczące planowania życia odnoszą się do kontekstualnie określonych możliwości, dynamiki procesów, nielinearnego progresu, zwielokrotnionych perspektyw i wzorów osobowych. Można mówić o wyraźnym przejściu od teorii "psychometrycznego ja”, złożonego ze zmiennych, w stronę ",ja" podlegającego narracji, konstruowanego za pomocą takich środków, jak historie i znaczenia ${ }^{70}$.

${ }^{67}$ Tamże, s. 33.

$68 \mathrm{~J}$. Guichard, Life-long self- construction, International Journal for Educational and Vocational Guidance, 2005, 5.

${ }^{69}$ M.L. Savickas, The Theory and practice of career construction.

70 R.V. Peavy, Poradnictwo socjodynamiczne. Praktyczne podejście do nadawania znaczeń, Bielsko-Biała 2014, s. 13. 
Konwencjonalne formy poradnictwa, jak podejście poznawczo-behawioralne, psychodynamiczne, czy humanistyczne, mają wartość potwierdzoną badaniami $^{71}$. Pisze o tej wartości także McMahon, przy omawianiu stworzonej przez siebie koncepcji (2014), jednak rozwinęły się w epoce przemysłowej pod wpływem pozytywistycznych nauk społecznych i, cytując Peavy`ego, można powiedzieć, że umysłowość doby industrialnej już nie wystarcza do zrozumienia współczesnej rzeczywistości i język pozytywistyczny zastępowany jest terminami charakterystycznymi dla konstruktywizmu, feminizmu, narracji, teorii systemów, teorii chaosu, etnografii, czy symbolicznego interakcjonizmu ${ }^{72}$. Dlatego, aby utrzymać swoje znaczenie i odpowiadać na potrzeby osób poszukujących pomocy we współczesnym społeczeństwie, poradnictwo także musi się zmieniać - zarówno w dziedzinie pojęć, jak i stosowanych metod ${ }^{73}$. Cytowany twórca podejścia socjodynamicznego w poradnictwie zakłada, że

koncepcje takie, jak narracja, symboliczna koordynacja działań społecznych, autokreacja, przestrzeń życiowa, perspektywa, postawy, założenia etyczne, konstrukcje umysłowe i nadawanie znaczeń, mają szanse być bardziej użyteczne dla zrozumienia ludzkich poczynań i dynamiki życia społecznego, niż koncepcje takie jak zmienne osobowościowe, cechy, klasyfikacje, zachowanie ${ }^{74}$.

Na przykład, narracje i „tematy życia” stanowią oś poradnictwa kariery opartego na konceptualnych propozycjach Savicasa, którego Teoria konstrukcji kariery wpisuje się w konstruktywizm i społeczny konstrukcjonizm, będąc równocześnie "rozwiniętą i uaktualnioną wersją koncepcji Supera"75 i zaliczana jest do bardziej znaczacych aktualnie teorii karier. Poradnictwo konstrukcji życia, jako odzwierciedlenie przesunięć paradygmatycznych $\mathrm{w}$ tej sferze, jest praktyczną aplikacją wspomnianej teorii76, mającej na gruncie polskim relatywnie bogate opracowania, tak $\mathrm{w}$ odniesieniu do założeń konceptualnych, jak i praktycznych zastosowań, szczególnie widoczne w pracach badaczy $\mathrm{z}$ wrocławskiej szkoły poradoznawstwa, dlatego $\mathrm{w}$ tym miejscu pominę jej omówienie.

W literaturze przedmiotu jako ważną dla poradnictwa kariery w świecie dynamicznych zmian, szans i wzrastającej złożoności ujmuje się Teorię cha-

71 Tamże, s. 5.

72 Tamże, s. 6.

${ }^{73}$ Tamże.

74 Tamże, s. 14.

${ }^{75}$ M. McMahon, New Trends in Theory Development in Career Psychology, s. 20.

${ }^{76}$ M.L. Savickas i in., Life designing: a paradigm for career construction in $21^{\text {st }}$ century, Journal of Vocational Behavior, 2011, 75. 
osu karier (CTC). V.C. Massaglia i J. Papenfuss ${ }^{77}$ omawiając naturę kariery „incydentalnej”, zwracają uwagę na praktyczną użyteczność tej teorii w poradnictwie, na jej szczególne wartości aplikacyjne. O żywotności i znaczeniu tej teorii dla praktyki mówi Peter Mcilveen ${ }^{78}$ we wstępie do specjalnego, wydanego w 2014 roku z okazji celebrowania dziesięciolecia statusu tej teorii, numeru Australian Journal of Career Development.

Również Pryor i Bright, twórcy Teorii chaosu karier, zwracają uwagę, że większość współczesnych teorii karier charakteryzują ograniczenia spowodowane ich pozytywistyczną orientacją i hipotetyczno-dedukcyjnym rozumowaniem. Wśród ograniczeń tych teorii podkreślają też ich ogniskowanie na perspektywie zachodniego indywidualizmu oraz brak odniesień kolektywistyczno-kulturowych ${ }^{79}$.

Teoria chaosu wpisuje się w podejście teorii systemów z zastosowaniem do wyjaśnienia fenomenów naturalnych, ze zwróceniem uwagi na ich strukturę i uporządkowanie. Zarówno jednostki, jak i środowisko postrzegane są przez pryzmat kategorii chaosu jako złożone, otwarte i adaptatywne systemy, które są ekstremalnie wrażliwe na zmiany. W rezultacie systemy te są uporządkowane, lecz nieprzewidywalne oraz adaptacyjne, w rozumieniu poszukiwania wzorów. Teoria chaosu zapewnia wgląd w złożoność, adaptacyjność, zmianę, szanse, nielinearność, kreatywność i historię, jako systemowe charakterystyki jednostek i środowisk ${ }^{80}$. Pryor i Bright podkreślają, że zbudowana przez nich teoria zawiera komponenty systemowe, realistyczne, konstruktywistyczne, ekologiczne, kontekstualne i, co oczywiste, elementy teorii chaosu. Unikalnością osoby jest zdolność do budowania kariery poprzez przyczynowe działania, które jednak mogą być nieodpowiednie, źle dostosowane, oparte na nieuświadomionych motywach, zracjonalizowane przez mechanizmy obronne, co buduje szczególne zapotrzebowanie na poradnictwo w sensie określania „nieadekwatności pewnych jednostkowych konstruktów rzeczywistości leżących u podstaw procesów podejmowania decyzji" ${ }^{81}$. Jak stwierdzają jej twórcy,

charakteryzujemy się tendencją do zaprzeczania rzeczywistości i oporem wobec jawiących się możliwości zmian, potrzebą linearnego postrzegania samych siebie, świata i rzeczywistości, jako całości, zakładając, że w ten sposób osiągamy kontrolę

77 Cew.wisc.edu/docs/R109ChaosTheory

78 Mc Ilveen P., Introduction to a good idea: Chaos theory of careers, Australian Journal of Career Development, 2014, 23(3).

79 R.G.L. Pryor, J.E. Bright, The Chaos Theory of Careers, Australian Journal of Career Development, Spring 2003, 12, 3.

80 Tamże, s. 16.

${ }^{81}$ Tamże, s. 17. 
nad własnym życiem i środowiskiem, czy też realizujemy w sposób nieprzerwany przyjęte wcześniej wzory działania ${ }^{82}$.

Teoria chaosu zakłada gwałtowne tranzycje z jednej fazy do drugiej, czy też z jednego przyjętego wzoru życia do innego, z jednej opcji karierowej do drugiej. Większość stosowanych teorii karier nie uwzględnia, zdaniem twórców CTC, takich elementów w rozwoju karier i podejmowaniu decyzji karierowych, jakimi są: złożoność ludzkiego doświadczenia i społecznego świata, zmiennej, dynamicznej, interaktywnej i adaptacyjnej natury ludzkiego działania, także w obszarze podejmowania decyzji odnośnie wyboru i przebiegu kariery, który wzbogacony być może przecież nieplanowanymi i nieprzewidywalnymi wydarzeniami i doświadczeniami ${ }^{83}$.

Jak podkreślają jej twórcy, poszukiwanie nowego podejścia owocnego dla praktyki poradniczej leżało u podstaw budowy CTC. Teoria ta powstała w odpowiedzi na potrzeby zmian i szans jawiących się w rozwoju karier, nie przebiegającej według znanej dotychczas trajektorii. Prawie wszystkie istniejące teorie karier, w argumentacji Pryora i Brighta, zakładały możliwość mapowania różnych systemów wpływów na jednostkę, z uwzględnieniem jednak stabilności i przewidywalności. Teorie te, mimo iż identyfikowały użyteczne dla praktyki aspekty rozwoju karier, miały jednak ograniczenia o charakterze częściowych tylko wyjaśnień, wąskiego zogniskowania i generalnie ograniczoną możliwość zastosowania zarówno do badań, jak i praktyki poradniczejes. Teoria CTC przyjmuje, że zarówno stabilność, jak i jej brak są inherentnymi właściwościami współczesności i względnie stały porządek świata musi być konfrontowany z niepewnością oraz brakiem stabilności. W przekonaniu autorów, CTC zapewnia nowe spojrzenie na naturę rozwoju karier, ukazuje ich wymiary często zaniedbywane przez współczesne wyjaśnienia, do których zaliczają: nowe wyzwania i możliwości jawiące się w tle niepewności, wymiar duchowości w rozwoju karier, poszukiwanie znaczeń, integrację „być” i „stawać się"85.

Teoria ta powstała pod wpływem intelektualnych założeń takich podejść, jak: kontekstualizm/ekologia, realizm/konstruktywizm i teoria systemów ${ }^{86}$. Założenia tej teorii zarysowują cztery kategorie pojęciowe: złożoność, zmiana, konstruktywność i szansa - „cztery C": complexity, change, constructiceness i chance.

\footnotetext{
82 Tamże.

83 Tamże, s. 13.

${ }^{84}$ R.G.L. Pryor, J.E. Bright, The Chaos Theory of Careers.

85 Tamże.

86 Tamże, s. 12-13.
} 
W poradnictwie kariery teoria chaosu jest relewantna jako podstawa praktyki zorientowanej na pomoc klientowi w radzeniu sobie ze złożonością, zmianą, ale również i szansami. Kluczowym pojęciem dla teorii Pryora i Brighta jest „złożoność” - złożoność procesów i czynników kształtujących życie każdej jednostki. Powoduje ona, że dokładne przewidywanie rozwoju kariery staje się wyzwaniem. Teoria chaosu zostawia przestrzeń dla różnych, nieprzewidywalnych, większych lub mniejszych zmian. Zamiast przewidywać rezultaty, teoria ta zakłada możliwość różnych wpływów. W zmieniającym się świecie rośnie na znaczeniu zdolność adaptacji jednostki do zmian, w związku z czym poradnictwo pomaga jej w odnajdowaniu się $\mathrm{w}$ sytuacjach tranzycji, zmian i adaptacji, pozwala jej konfrontować się $\mathrm{z}$ niepewnością $\mathrm{w}$ myśleniu i działaniu. Radzenie sobie $\mathrm{z}$ niepewnością to podstawowe wyzwanie związane $\mathrm{z}$ rozwojem kariery, co dla poradnictwa stwarza ogromne wyzwania. Potrzebą staje się nie uczenie klienta tego, jak opracowywać "dobry” plan związany z przebiegiem kariery, ale wyposażanie go, jak ujmują to jej twórcy, w kompetencje niezbędne do planowania, takie jak: umiejętność stworzenia i opracowania planu, jego korygowania, umiejętność kompromisu, opóźnienia, przyspieszenia, zmiany, przywrócenia, wdrożenia ${ }^{87}$, co oznacza zmianę określonej filozofii działania $\mathrm{z}$ "planning" na "planfulness". Staranne i ostrożne planowanie w perspektywie przewidywalności jest zastępowane pojęciem „wyłaniania się", ,jawienia się" (emergence), szans, możliwości, trudności, nadającym sens przeszłym i potencjalnym doświadczeniom w przyjętym modelu „złożoności”.

Wykorzystanie CTC $\mathrm{w}$ poradnictwie kariery nie wymaga nowych narzędzi diagnostycznych. Zastosowanie również mają tu techniki klasyczne, nie wyłączając tych, które bazują na podejściu cechy i czynnika. Nacisk położony jest na pomoc klientowi w lepszym zrozumieniu jego konwergentnych i emergentnych (kategorie pojęciowe istotne dla CTC) jakości. Cechy konwergentne to takie, które właściwe są każdej jednostce i składają się na nie: umiejętności, wartości, IQ, wiedza, cechy poddające się oszacowaniu i pomiarowi. Cechy emergentne natomiast są efektem złożonych interakcji wielu zróżnicowanych czynników, które kształtują zachowania karierowe ${ }^{88}$. Diagnoza tych cech jest w doradztwie dużym wyzwaniem, gdyż są one unikalne dla poszczególnych jednostek, decydując często o przebiegu ich karier. Wspomagać klienta $\mathrm{w}$ tym ujęciu to, pomóc mu $\mathrm{w}$ rozumieniu tego, że zmiany nie muszą mieć charakteru linearnego, ukazanie mu, że ograniczenia wiedzy i kontroli nie oznaczają niemożności podejmowania decyzji ${ }^{89}$.

87 Tamże.

88 R.G.L. Pryor, J.E. Bright, Counseling Chaos: techniques for practitioners, Journal of Employment Counseling, 2006, 43(1), s. 4.

${ }^{89}$ Massaglia, Papenfuss, cev.wisc.edu/docs/. 
Jak pokazują N. Amudson, K.M. Mills i B.A. Smith, kompleksowa, globalna, nieprzewidywalna natura współczesnego rynku podważa założenia i mity tradycyjnych teorii karier. Badacze ci podkreślają równocześnie potrzebę nowego podejścia, umożliwiającego $\mathrm{w}$ znacznie większym stopniu nawigowanie doświadczeniem karierowym i oczekiwania takie łączą z teorią chaosu karier, którą opisują jako obszerną ramę konceptualną, obejmującą złożoność i zmiany zachodzące na rynku pracy. W ich przekonaniu CTC pozwala na bardziej otwarte, elastyczne, dynamiczne i kreatywne podejście $\mathrm{w}$ poradnictwie ${ }^{90}$. W tym podejściu $\mathrm{W}$ procesie doradczym uświadamia się klienta, że rzeczywistość przejawia się w bezustannych zmianach i oparta jest na samoorganizacji i szansach, a życie to zarówno uporządkowanie, jak też brak wzorów i możliwości przewidywania. Uporządkowanie i zróżnicowanie mogą pojawiać się w tym samym czasie. Ukazanie tych procesów klientowi, pomoc $\mathrm{w}$ rozpoznaniu nieprzewidywalnych zdarzeń, uświadomienie mu, że wzrastająca złożoność rzeczywistości prowadzi do zmniejszenia możliwości przewidywania rezultatów, ukazanie różnic w myśleniu emergentnym i konwergentnym, ukazanie konieczności podejmowania decyzji nawet $\mathrm{w}$ sytuacjach ograniczonej wiedzy na temat możliwych wpływów i pożądanych rezultatów, wzmocnienie potrzeby podejmowania wyzwań, to $\mathrm{w}$ praktyce poradniczej poszukiwanie dróg do wzmocnienia kreatywności jednostki na drodze konstruowania ścieżki kariery ${ }^{91}$. CTC, w ujęciu jej twórców, zapewnia najpełniejsze i najbardziej spójne wyjaśnienie zachowań karierowych, które zawiera zarówno modernistyczną, jak i postmodernistyczną perspektywę ${ }^{92}$.

$\mathrm{W}$ ten sam nurt szerokiego podejścia do kariery - $\mathrm{w}$ zmiennym i nieprzewidywalnym świecie, jej rozwoju i zmian - wpisuje się też teoria uczenia się z przypadków (ze zbiegów okoliczności) Krumboltza (The Happenstance Learning Theory), również, jak określa ją jej autor, mająca charakter wszechstronnego, szerokiego ujęcia teoretycznego. Jak stwierdza, nasza wiedza dotycząca przyszłości, przeznaczenia każdej jednostki, jest bardzo ograniczona, a mimo tego chcemy poznać czynniki określające nasze przeznaczenie "i nie pretendując do oryginalności”, korzystając z dorobku poprzedników, chce wydobyć z dotychczasowego dorobku tak badawczego, jak i teoretycznego, to co najistotniejsze i przedstawić teorię dającą prak-

${ }^{90}$ N.E. Amundson, K.M. Mills, B.A. Smith, Incorporating chaos and paradox into career development, Australia Journal of Career Development, April 2014, 32, 1.

${ }^{91}$ W. Patton, M. McMahon, Career development and systems theory: Connecting theory and practice, Rotterdam 2006.

${ }^{2}$ R.G.L. Pryor, J. Bright, The Chaos Theory of Career (CTC), s. 37. 
tyczne korzyści ${ }^{93}$. HTL zakłada, że ludzkie zachowania są produktem niezliczonej ilości doświadczeń uczenia się, dostępnych zarówno w planowanych, jak i nieplanowanych sytuacjach. Rezultatem tych doświadczeń są umiejętności, zainteresowania, wiedza, przekonania, preferencje, emocje, a także przyszłe działania. Sytuacje, w jakich znajduje się jednostka są po części rezultatem oddziaływań czynników, nad którymi nie ma ona kontroli, po części zaś rezultatem działań, które jednostka inicjuje sama. Koncentracja wyłącznie na strefach naszych wpływów może prowadzić do przeceniania naszych własnych możliwości oddziaływania na rzeczywistość, jednak każda sytuacja może być postrzegana równocześnie jako stwarzająca potencjalne możliwości poddające się kapitalizacji, a więc niejako do wykorzystania przez jednostkę. HTL jest modyfikacją wcześniej wyartykułowanych przez Krumboltza założeń teoretycznych dotyczących kariery ${ }^{94}$.

HCT zakłada, że przeznaczenie kariery jednostki trudno przewidzieć, bowiem jest ona funkcją planowanych i nieplanowanych doświadczeń związanych z uczeniem się. We wcześniejszych ujęciach teoretycznych rozwoju kariery - planowanych zbiegów okoliczności (Planned Happenstance) Krumboltz ${ }^{95}$ (1998) mówi, że nawet kiedy nie jesteśmy w stanie przewidzieć rezultatów naszych działań z powodu ograniczenia wiedzy w tym zakresie i braku możliwości kontroli, należy podjąć ryzyko.

Założenia HCT przekładają się na praktykę poradniczą. Działania doradcze, $w$ tym ujęciu to ukazywanie klientowi możliwości, jakie się pojawiają w trakcie niespodziewanych zdarzeń, co pozwala mu zrozumieć niepewną i niestałą naturę karier i korzystanie z pojawiających się szans, nawet gdyby one miały przybrać postać radykalnej zmiany kierunku kariery. Inne wskazania wpisujące się $w$ nurt tych samych porad karierowych mówią: podejmij się nowych, nieplanowanych wyzwań, uczestnicz w nieplanowanych wydarzeniach, spróbuj, podejmij ryzyko nawet kiedy nie znasz możliwych rezultatów, bądź zawsze otwarty na nowe rozwiązania, idź do przodu i popełniaj błędy, poszukuj wzorów, osób, z którymi się identyfikujesz, eksperymentuj z nowymi rolami ${ }^{96}$.

93 J.D. Krumboltz, The Happenstance Learning Theory, Journal of Career Assessment, May 2009, 17, 2, s. 135.

${ }^{94}$ J.D. Krumboltz, Serendipity is not serendipitous, Journal of Counseling Psychology, 1998, 45, s. 390-392; J.D. Krumoltz, S.J. Henderson, A Learning theory for career counselors, [w:] Adult career development: Concepts, issues and practices, red. S.G. Niles, National Career Development Association, Tulsa 2002, s. 41-58; J.D. Krumboltz, A.S. Levin, Luck is no accident. Making the most happenstance in your life and career, Atascadero 2004, za: J.D. Krumboltz, The Happenstance Learning Theory, s. 136.

${ }^{95}$ J.D. Krumboltz, Serendipity is not serendipitous.

${ }_{96}$ Cew.wisc.edu/docs/ 
Doradcy zawodowi ułatwiają proces uczenia się poprzez pomoc klientowi $\mathrm{w}$ projektowaniu aktywności angażujących, które można kapitalizować, uczą bycia wrażliwym na alternatywne rozwiązania, działania eksploracyjne.

Celem poradnictwa kariery nie jest, w ujęciu Krumboltza, pomoc klientowi w podejmowaniu pojedynczych decyzji karierowych, lecz wzmacnianie go $w$ podejmowaniu działań umożliwiających bardziej satysfakcjonujące życie, także $w$ obszarach związanych $\mathrm{z}$ karierą, działań eksploracyjnych, będących drogą do generowania korzystnych, nieplanowanych zdarzeń. Autor teorii HCT zwraca uwagę, że stosowanie narzędzi diagnostycznych, i tym samym ocena, służy nie łączeniu charakterystyk indywidualnych z charakterystykami zawodowymi, lecz stymulowaniu procesu uczenia się?7.

Przykładem szerokiego ujęcia kariery, poszukiwania możliwości opisowych i interpretacyjnych do fenomenu kariery, w różnych orientacjach teoretycznych i metodologicznych, jest także Ramowa teoria systemów (Systems Theory Framework of Career Development - STF) Patton i McMahon, której omówienie ukazało się w 1995 roku w Australian Journal of Career Development jako propozycja powstała $\mathrm{w}$ odpowiedzi na toczącą się we wczesnych latach dziewięćdziesiątych XX wieku debatę na temat potrzeby i możliwości konwergencji różnych teorii rozwoju kariery ${ }^{98}$. Potrzeby takie, systemowego spojrzenia na rozwój kariery, artykułowane były przez różnych badaczy 99 .

STF opisywana jest jako układ wzajemnie zależnych kręgów, z których każdy reprezentuje system wpływów na rozwój kariery jednostki. W centrum STF umieszczony jest system indywidualny jednostki, uwzględniający wartości, osobowość, zainteresowania, płeć. Jak omawia to zagadnienie McMahon, wiele z tych czynników wpływów wyjaśniają teorie karier wpisujące się $\mathrm{w}$ filozofię pozytywistyczną, jak na przykład szczegółowe wyjaśnienia wartości zawarte $\mathrm{w}$ ustaleniach Browna, czy prezentowane przez teorię Hollanda wyjaśnienia odnoszące się do osobowości. Z perspektywy STF wiele z tych wpływów może być wyjaśnianych przez subiektywne narracje jednostek i równocześnie przez teorie i badania prowadzone w różnych dyscyplinach ${ }^{100}$. Otaczający system jednostki system społeczny, w ramach którego sytuuje się rodzina, szkoła, grupy społeczne i szerszy w stosunku do niego system społeczno-środowiskowy, obejmujący system takich wpływów

${ }^{97}$ J.D. Krumboltz, The Happenstance Learning Theory.

98 M. McMahon, New Trends in Theory Development in Career Psychology.

99 Osipow, 1983; McMahon, Patton, 1995; Patton, McMahon, 1999, 2006; Pryor, Bright, 2011; Young i in., 2011, za: M. McMahon, New Trends in Theory Development in Career Psychology.

100 M. McMahon, New Trends in Theory Development in Career Psychology, s. 21. 
jak globalizacja, warunki socjoekonomiczne czy uwarunkowania terytorialno-przestrzenne nie często, jak wskazuje McMahon, były uwzględniane $\mathrm{w}$ psychologii karier, dlatego metateoretyczna orientacja STF akomoduje szczegółowe wyjaśnienia analizowanych zjawisk z innych dyscyplin, jak na przykład osiągnięcia psychologii organizacji, czy ekonomiczny wgląd w mechanizmy rynku ${ }^{101}$.

Tradycyjne teorie karier sformułowane zostały, jak już podkreślałam wcześniej, w świecie, który charakteryzował relatywnie wysoki poziom homogeniczności, natomiast kontekstualno-kulturowa heterogeniczność populacji, na potrzeby której odpowiadają współczesne teorie, powoduje to, że w obszarze wyjaśnień tych teorii pojawiają się takie pojęcia jak "szanse", czego przykładem jest STF, która włącza szanse do wielości czynników kształtujących proces rozwoju kariery. Konceptualizację złożoności jej fenomenu ułatwia myślenie systemowe, ewidentne $\mathrm{w}$ podejściach poradniczych postrzegających klienta holistycznie, w całej złożoności kontekstu jego życia, czego przykładem jest wspomniana wcześniej koncepcja aktywnego zaangażowania Amundsena, narracyjne poradnictwo kariery Cohrana, McMahon i Watsona opowiadanie historii życia, socjodynamiczne podejście Peary'ego, czy konstruowanie życia Savicasa.

Jak widać z przeprowadzonych analiz, konstruktywizm i problem integracji teorii to kluczowe tematy jawiące się $\mathrm{w}$ najnowszej literaturze dotyczącej rozwoju karier102. Teoria Patton i McMahon nie jest, w interpretacji autorek, teorią, a raczej metateoretyczną ramą, wykorzystującą różne teorie, zarówno osadzone $\mathrm{w}$ pozytywistycznym oglądzie świata, $\mathrm{z}$ odniesieniami do danych obiektywnych i logicznych, racjonalnych procesów, jak również oparte na dokonaniach konstruktywizmu, z naciskiem na holizm, podmiotowość, nadawanie znaczeń i wzajemne związki między czynnikami wpływów ${ }^{103}$. Ta zarysowująca się orientacja w kierunku integracji i konwergencji różnych teorii karier sprzyja także jakości poradnictwa karier, bowiem osiągnięcia konstruktywizmu, teorii systemów, teorii działań, jak wskazują niektórzy autorzy, pozwalają na wielowymiarowe odniesienia do procesu rozwoju jednostki w różnych obszarach jej życia.

Mówiąc o wartościach aplikacyjnych STF, McMahon, Watson i Patton zwracają uwagę na szeroki wachlarz możliwości jej zastosowania - w różnych środowiskach kulturowych, różnych instytucjach, w odniesieniu do zróżnicowanych kategorii wiekowych klientów, mówią też o wartości jako-

101 Tamże.

102 M. McMahon, M. Watson, W. Patton, Context - Resonant Systems. Perspectives in Career Theory, s. 33.

103 Tamże, s. 34. 
ściowych narzędzi ocen zbudowanych na jej bazie oraz o stymulowaniu rozwoju podejść narracyjnych w poradnictwie, pozwalających jednostkom konstruować własne historie, dopuszczać do głosu ich doświadczenie zdobyte $\mathrm{w}$ przeżytych przez nich sytuacjach, postrzeganych $\mathrm{z}$ ich perspektywy ${ }^{104}$. Zwrot paradygmatyczny w poradnictwie kariery to nowe perspektywy teoretyczne, opierające się na konstruktywizmie, odejście od poradnictwa dyrektywnego i poszukiwanie narracyjnych metod pracy105. W ten nurt wpisuje się także Ramowa teoria systemów rozwoju karier, STF.

W literaturze przedmiotu podkreśla się, że w poradnictwie ery przemysłowej nacisk położony był na techniki zmiany osobowości i behawioralnego przystosowania, współczesne orientacje w poradnictwie doskonale obrazuje także podejście socjodynamiczne, które zakłada wpływ relacji społecznych na dynamiczne procesy konstruowania własnego "ja” przez jednostkę. W podejściu tym zwraca się uwagę na relacyjny aspekt ludzkiego doświadczenia. $Z$ racji skupienia się na kontekście społecznym, perspektywa socjodynamiczna sytuuje się obok innych podejść relacyjnych, takich jak społeczny konstruktywizm Michaela Mahoneya, konstruktywizm społeczny Kena i Mary Bergen oraz pewnych sposobów myślenia narracyjnego ${ }^{106}$.

Twórca podejścia socjodynamicznego Vance Peavy mówi o podejściu wrażliwym na różnice, zwraca uwagę na inteligencję kulturową potrzebną do pracy $\mathrm{w}$ poradnictwie, zestrojeniu kulturowym (cultural attunment) ${ }^{107}$, wadze uważnego wsłuchiwania się $\mathrm{w}$ znaczenia tworzone przez ludzi w związku z ich tożsamością etniczną, zakładając, że istnieje zestaw narzędzi kulturowych, których można użyć, aby zrozumieć, jak status etniczny czy społeczno-ekonomiczny ukształtowały historię życia osoby.

V. Peavy, jak wskazuje Hoskins, opierał się na teoriach uchodzących za postmodernistyczne. Jego wiara w jaźń jako zróżnicowaną wielość współtworzoną, narracyjną i wysoce relacyjną pozwala sytuować jego prace $\mathrm{w}$ ramach tego paradygmatu. Według twórcy tego podejścia $\mathrm{w}$ poradnictwie, ludzie, którzy są społecznymi aktorami i podmiotami moralnymi używają języka, aby budować złożone, ustrukturyzowane systemy znaczeń108. W tym podejściu zakłada się wartość dialogicznego podejścia, przyjmując, że dialog wraz ze słowami, symbolami i metaforami nie ma znaczenia poza kontekstem, w którym się rodzi, krytykując zachodnią psy-

104 Tamże, s. 39.

105 A. Bilon, Wspótczesne tendencje w badaniach poradnictwa kariery; J. Minta, Od aktora do autora. Wspieranie młodzieży w konstruowaniu własnej kariery.

106 M.L. Hoskins, Wrowadzenie do dorobku Vance`a Peavy ego, [w:] Poradnictwo socjodynamiczne, s. X-XI.

107 Tamże, s. XII.

108 Tamże, s. XI. 
chologię i dekonstruując dziedzictwo behawioryzmu jako perspektywę nieużyteczną w świecie wielości nasycenia i złożoności. Twórca tego podejścia w poradnictwie zakładał potrzebę porzucenia myślenia o ludziach jako konstelacjach cech i czynników, zamiast tego zaś wskazywał na konieczność traktowania każdej osoby jako jednostki zajmującej swoją unikalną przestrzeń życiowąą ${ }^{109}$ W ujęciu tym podkreśla się, że takie pojęcia, jak narracja, symboliczna koordynacja działań społecznych, autokreacja, przestrzeń życiowa, postawy, założenia etyczne, konstrukcje umysłowe, czy nadawanie znaczeń są bardziej przydatne dla rozumienia ludzkich działań i dynamiki życia społecznego, niż takie pojęcia jak zmienne osobowościowe, cechy, klasyfikacje i zachowania ${ }^{110}$. V. Peavy definiował poradnictwo jako

proces uczenia się, współkonstruowania nowej rzeczywistości i planowania życia (...) jako środek poszerzający perspektywy, umożliwiający wybory, dający nowe szanse, zwiększający przestrzeń osobistej wolności ${ }^{111}$.

Wskazywał, że idee kierują naszymi działaniami w życiu, pomagają zajmować określone stanowiska, planować, dokonywać wyborów, konstruować swoje życie, intensyfikować wysiłek, przezwyciężać ograniczenia i podejmować próby życiowego rozwoju, a poradnictwo jest pomaganiem w refleksji nad tymi ideami ${ }^{112}$. W ujęciu tym

proces poradniczy i wszelkie rozwiązania proponowane przez poradnictwo to osiągnięcia interaktywne - wynegocjowane między pomagającym a potrzebującym pomocy, proces ten jest językową grą konstruowania znaczeń i symbolicznej interakcji113.

Omawiając koncepcje poradnictwa V. Peavy'ego, warto jeszcze raz podkreślić, że podejście socjodynamiczne zwraca uwagę na kontekst, działania społeczne oraz zależności w tworzeniu relacji społecznych i jednostkowych. Model socjodynamiczny pomaga doradcom przejść z monokulturowego, hermetycznego zamknięcia $\mathrm{w}$ myśleniu i praktyce ku wielokulturowemu zaangażowaniu i zogniskowaniu na znaczeniu procesu interakcji114. Zwolennicy podejścia socjodynamicznego uważają, że praktyki wrażliwe kulturowo pozwalają uniknąć działań opresyjnych, występujących w poradnictwie tradycyjnym.

\footnotetext{
109 Tamże, s. XIV.

110 R.V. Peavy, Poradnictwo socjodynamiczne, s. 14.

111 Tamże, s. 2.

112 Tamże, s. 3.

113 Tamże, s. 5.

114 Tamże.
} 
Jak zostało ukazane, co stanowi założenie niniejszego artykułu, dynamika zmian $\mathrm{w}$ obszarze teorii karier ma wyraźne przełożenie na praktykę. Nowe koncepcje, jak na przykład idea poradnictwa konstruowania życia (life design counselling) i skupieni wokół jej propagowania badacze, oferują praktyce poradniczej wieloaspektowy model teoretyczny oraz propozycję praktyki

której struktura działania ma holistyczny i całożyciowy charakter, a odnosi się zarówno do kontekstów, w jakich ludzie konstruują własne życie, jak i do tych, w jakich dzieje się poradnictwo ${ }^{115}$.

Podejście to, jak wskazuje Minta powołując się na opinię jego twórców, to kolejny etap w rozwoju poradnictwa. Jest ono przykładem zmian paradygmatycznych $\mathrm{w}$ obszarze rozwoju karier116. Powyższe analizy obrazują, że zarówno koncepcje teoretyczne, jak i powstające na ich przesłankach orientacje praktyczne odzwierciedlają i odpowiadają na zmienne wyzwania współczesności.

Mając na uwadze rosnące trudności życia w społeczeństwie ponowoczesnym i równocześnie rosnące możliwości działań związane z gwałtownym rozwojem technologicznym, oraz dalej $\mathrm{z}$ jednej strony nawarstwianie się problemów będących, jak wskazuje M. Marody, ubocznymi skutkami modernizacji, które są efektem ekspansji procesów „urynkowienia” społeczeństwa, takich jak choćby bezrobocie czy rozpad znaczeń, nadających sens działaniom społecznym ${ }^{117}$, także przecież powiązanych ze sferą pracy i z drugiej strony, osadzenie praktyk jako reakcji na te problemy, w „masowej komunikacji zindywidualizowanej"118, a przede wszystkim transformujący wpływ gospodarki na naturę pracy, ulegającej "dematerializacji” wraz z organizowaniem jej nie tyle wokół wytwarzania przedmiotów, ile wokół operowania abstraktami i ideami $\mathrm{w}$ procesie przechodzenia do gospodarki opartej na wiedzy ${ }^{119}$, można zakładać dalsze przeobrażenia we wzorach przebiegu karier. Nasuwa się w związku z tym pytanie o aktualność wpisujących się $\mathrm{w}$ nurt przeobrażeń paradygmatycznych teorii karier i wyrastających na nich praktyk poradniczych.

O zwrocie paradygmatycznym $\mathrm{w}$ poradnictwie kariery, przejawiającym się przyjęciem nowych perspektyw teoretycznych, jakościowych metod ba-

\footnotetext{
115 J. Minta, Od aktora do autora, s. 35.

116 Tamże.

${ }_{117}$ M. Marody, Jednostka po nowoczesności, s. 311.

118 Tamże, s. 311.

119 Tamże, s. 130.
} 
dawczych, przejściem od poradnictwa dyrektywnego w kierunku narracyjnych metod pracy z klientem, piszą także polscy badacze ${ }^{120}$.

Jak wynika $\mathrm{z}$ przedstawionych $\mathrm{w}$ niniejszym artykule rozważań, płodnym nurtem teoretycznym $w$ analizach dotyczących karier stał się konstruktywizm, na gruncie którego łatwiejsze staje się rozumienie samej kariery jako subiektywnej konstrukcji, całożyciowego procesu, a także rozumienie przeobrażeń we wzorach przebiegu karier, ogólnie rzecz ujmując - od linearnych do zmiennych, proteuszowych, bez granic, jawiących się w tle określonych zmian społecznych, ekonomicznych, czy też technologicznych i raczej indywidualnego, a nie organizacyjnego procesu jej planowania. Nacisk na rdzenność teorii i praktyk poradniczych, znaczenie kulturowego kontekstu i środowiskowych wpływów na kształt i przebieg karier oraz równocześnie potrzebę konwergencji w obszarze ujęć teoretycznych, a także artykułowanie potrzeb interdyscyplinarnych podejść do wyjaśniania fenomenu zmienności kariery odzwierciedla literatura przedmiotu. Można mówić o wyraźnym przesunięciu paradygmatycznym, choć należy mocno podkreślić, iż wielu badaczy, także na gruncie polskim, zwraca uwagę na równoczesne funkcjonowanie dwóch paradygmatów - poszukującego epistemologicznej pewności i paradygmatu, który „zaakceptował epistemologiczną niepewność"121. Na istniejącą w omawianym dyskursie „niespójność” zwraca uwagę A. Bilon, która pisze, że mimo iż podkreśla się znaczenie nowego paradygmatu $\mathrm{w}$ badaniach nad poradnictwem kariery, to równocześnie widoczne zarówno $\mathrm{w}$ badaniach, jak i $\mathrm{w}$ praktyce istnieje poszukiwanie "skutecznych" metod, „właściwego" modelu pracy, zaś dyskurs i badania nie są „wolne” od prognoz rozwoju kariery, analiz skuteczności poradnictwa, prognoz jego rozwoju, a przede wszystkim od celów przypisywanych mu w paradygmacie modernistycznym, to znaczy od presji decydentów na cele ogólnospołeczne, mimo faktu, że za sukces życiowy czyni się odpowiedzialną samą jednostkę mającą się elastyczne adaptować do wymagań rynku pracy ${ }^{122}$. W wyjaśnieniach analizowanego fenomenu A. Kargulowa mówi, że jednoczesne funkcjonowanie obu paradygmatów jest być może powiązane $\mathrm{z}$ faktem, że $\mathrm{w}$ proces poradnictwa uwikłanych jest wielu „organizatorów życia społecznego ${ }^{123}$. Dotykam w tym miejscu, wprawdzie sygnalnie tylko, że jest to problem, ze względu na jego rangę, wymagający

120 A. Bilon, Wspótczesne tendencje w badaniach poradnictwa kariery; J. Minta, Od aktora do autora; B. Wojtasik, Refleksyjne konstruowanie kariery życiowej w ponowoczesnej codzienności.

${ }^{121}$ B. Wojtasik, Refleksyjne konstruowanie kariery życiowej w ponowoczesnej codzienności; A. Bilon, Wspótczesne tendencje w badaniach poradnictwa kariery.

122 A. Bilon, Wspótczesne tendencje w badaniach poradnictwa kariery, s. 50.

${ }^{123}$ A. Kargulowa, Poradnictwo ery komunikacji satelitarnej, Studia Poradoznawcze, 2012. 
szerszego opracowania, kwestii politycznego aspektu poradnictwa, jego miejsca w różnego rodzaju strategiach sektorowych formułowanych na poziomie globalnym, regionalnym czy też lokalnym ${ }^{124}$, założeń i badań dotyczących jego efektywności w kontekście potrzeb rynku pracy, czy adaptacyjności, zatrudnialności (employability) jednostki, czy wreszcie szerzej neoliberalnej polityki społecznej, ideowych i ideologicznych aspektów poradnictwa ${ }^{125}$. Sygnalnie również, w tym miejscu, traktuję kwestie zarzutów wobec konstruktywizmu i wyrosłych na jego przesłankach podejść w poradnictwie, dotyczących niedostatecznego uwzględniania społecznych aspektów życia człowieka oraz przecenianie jego sprawczości (agency) ${ }^{126}$, wymagających odrębnych opracowań.

Rozwijanie teorii, jak pisze A. Kargulowa, dających nadzieję „na opisanie, zrozumienie i wyjaśnienie sensu własnego istnienia we współczesnej rzeczywistości i roli $\mathrm{w}$ niej poradnictwa"127 wymaga zbiorowego wysiłku zarówno badaczy, jak i refleksyjnych praktyków zaangażowanych w obserwowanie, analizowanie i teoretyzowanie, w ramach wielu podejść128, co ułatwia rozumienie złożonej rzeczywistości, w której żyjemy i wyzwań wobec których stoimy. Można zatem mieć nadzieję, że nowe trendy przybierające postać bardziej holistycznych i inkluzyjnych wyjaśnień wzorów przebiegu karier, a równocześnie bliższe związki teorii i badań z praktyką poradniczą $\mathrm{w}$ analizowanym obszarze, $\mathrm{w}$ połączeniu $\mathrm{z}$ dorobkiem tradycyjnych teorii karier pozwolą na lepsze poruszanie się jednostki w zmiennym świecie pracy i konstruowanie własnego życia wokół przyjętych wartości i oczekiwań w różnych kontekstach kulturowych oraz podnoszenie jakości życia poprzez wykorzystanie jawiących się szans i „,szczęśliwych przypadków", a także traktowanie niepowodzeń i ograniczeń jako możliwości rozwoju i całożyciowego uczenia się.

\section{BIBLIOGRAFIA}

Amundson N.E., Essential Elements of Career Counseling. Processes and Techniques (3rd Edition), The Merrill Counseling Series, 2013.

Amundson N.E., Mills K.M., Smith B.A., Incorporating chaos and paradox into career development, Australia Journal of Career Development, April, 2014, 32, 1.

124 E. Solarczyk-Ambrozik, Społeczno-ekonomiczne wyznaczniki zapotrzebowania na doradztwo zawodowe, Studia Edukacyjne, 2008, 7.

${ }^{125}$ A. Kargulowa, O potrzebie badań poradoznawczych. Ku antropologii poradnictwa, Studia Poradoznawcze, 2013.

${ }^{126}$ A. Bilon, Wspótczesne tendencje w badaniach poradnictwa kariery, s. 52.

127 A. Kargulowa, Poradnictwo ery komunikacji satelitarnej, s. 31.

128 Tamże. 
Alurmani G., Striking the right note: The cultural preparedness approach to developing resonant career quidance programmes, International Journal for Educational and Vocational Guidance, 2011, 11.

Alurmani G., Anuradha J.B., Leong T.L., Watts A.G., The Manifestation of Career, [w:] Handbook of Career Development, International Perspectives, red. Alurmani G., Springer, New York 2014.

Arthur M.B., Examining contemporary careers. A call for interdisciplinary inquiry, Human Relations, 2008, 6.

Bańka A., Psychologiczne doradztwo karier, Wydawnictwo Print-B, Poznań 2007.

Bilon A., Wspótczesne tendencje w badaniach poradnictwa kariery, Studia Poradoznawcze, 2013.

Blustein D.L., Vocational Psychology at the fork in the Road: Staying the course or taking the road less traveled, Journal of Career Assessment, 2011, 19.

Bretz R.D. Jr., Judge T.A., Person - Organization Fit and the Theory of Work Adjustement: Implications for Satisfaction, Tenure and Career Success, Journal of Vocational Behavior, 1994, 44.

Bright J.E., Pryor R.G.L., Chaos in practice: Techniques for career counselors, Australian Journal of Career Development, 2005, 14(1).

Cybal-Michalska A., Młodzież akademicka a kariera zawodowa, Oficyna Wydawnicza Impuls, Kraków 2013.

Davis R.V., The Minnesota theory of work adjustment, [w:] Career Development and Counseling. Putting Theory and Research to Work, red. D. Brown, R.T. Lent, Wiley, New York 2005.

Gottfredson L.S., Applying Gottfredson`s Theory of Circumscription and Compromise in Career Guidance and Counselling, [w:] Career Development and Counseling. Putting Theory and Research to Work, red. S.D. Brown, R.W. Lent, Wiley, New York 2005.

Guichard J., Life-long self-construction, International Journal for Educational and Vocational Guidance, 2005, 5 .

Hackett G., Lent R.W., Greenhaus J.H., Advances in vocational theory and research: A 20 years retrospective, Journal of Vocational Behaviour, 1991, 38.

Hall D.T., Mirvis P.H., The new protean career: Psychological success and the path with a heart, [w:] The career is dead - long live the career, red. D.T. Hall, Jossey - Bass, San Francisco 1996.

Herr E.L., Super's life - span, life - space approach and its outlook for refinement, The Career Development Quarterly, 1997, 45.

Hoskins M.L., Wprowadzenie do dorobku Vance`a Peavy `ego, [w:] Poradnictwo socjodynamiczne. Praktyczne podejście do nadawania znaczeń, red. R.V. Peavy, Taos Institute, BielskoBiała 2014.

Kargulowa A., Poradnictwo ery komunikacji satelitarnej, Studia Poradoznawcze, 2012.

Kargulowa A., O potrzebie badań poradoznawczych. Ku antropologii poradnictwa, Studia Poradoznawcze, 2013.

Kidd J.M., Understanding Career Counselling. Theory, Research and Practice, Sage Publications, London 2006.

Krumboltz J.D., Serendipity is not serendipitous, Journal of Counseling Psychology, 1998, 45.

Krumboltz J.D., The Happenstance Learning Theory, Journal of Career Assessment, May 2009, 17, 2. 
Krumoltz J.D., Henderson S.J., A Learning theory for career counselors, [w:] Adult career development: Concepts, issues and practices, red. S.G. Niles, National Career Development Association, Tulsa 2002.

Krumboltz J.D., Levin A.S., Luck is no accident. Making the most happenstance in your life and career, Impact Publishers, Atascadero 2004.

Lent R.W., Brown S.D., Hackett G.I., Social cognitive career theory, [w:] Career choice and development, CA: Jossey-Bass, San Francisco 2002.

Leung S.A., The Big Five Career Theories, [w:] International Handbook of Career Guidance, International Perspectives, red. J.A. Athanasou, R. Van Esbroeck, Springer, New York 2008.

Marody M., Jednostka po nowoczesności. Perspektywa socjologiczna, Wydawnictwo Naukowe Scholar, Warszawa 2014.

Massaglia V.C., Papenfuss J., The Incidental Career. Chaos Theory and Career Development, www. Cew.wisc.edu/docs/R109Chaos TheoryVictor Massaglia and Janine Papenfus.pdf.

Mc Ilveen P., Introduction to a good idea: Chaos theory of careers, Australian Journal of Career Development, 2014, 23(3).

McMahon M., New Trends in Theory Development in Career Psychology, [w:] Handbook of Career Development. International Perspectives, red. G. Alurmani et al., Springer Science Buisiness Media, 2014.

Mc Mahon M., Watson M., Patton W., Context - Resonant Systems. Perspectives in Career Theory, [w:] Handbook of Career Development. International Perspectives, red. G. Alurmani i in. Springer, New York 2014.

Minta J., Od aktora do autora. Wspieranie młodzieży w konstruowaniu własnej kariery, KOWEZiU, Warszawa 2012.

Paszkowska-Rogacz A., Psychologiczne podstawy wyboru zawodu. Przeglad koncepcji teoretycznych, KOWEZiU, Warszawa 2003.

Paszkowska-Rogacz A., Doradztwo zawodowe, Wydawnictwo Difin, Warszawa 2009.

Patton W., McMahon M., Career development and systems theory: A new relationship, Pacific Grove, CA: Brooks/Cole 1999.

Patton W., McMahon M., Career Development and Systems Theory: Connecting Theory and Practice, The Netherlands: Sense Publishers, Rotterdam 2006; 3 ${ }^{\text {rd }}$ ed, RotterdamBoston 2014.

Peavy R.V., Poradnictwo socjodynamiczne. Praktyczne podejście do nadawania znaczeń, Taos Institute, Bielsko-Biała 2014.

Pryor R.G.L., Bright J.E., The Chaos Theory of Careers, Australian Journal of Career Development, Spring 2003, 12, 3.

Pryor R.G.L., Bright J.E., Counseling Chaos: techniques for practitioners, Journal of Employment Counseling, 2006, 43(1).

Pryor R.G.L., Bright J.E., The Chaos Theory of Career: A New Perspective on Working in the Twenty - First Century, Routledge, New York 2011.

Pryor R.G.L., Bright J., The Chaos Theory of Career (CTC): Ten years on and only just began, Australian Journal of Career Development, April 2014, 23(1).

Savickas M., The theory and practice of career construction, [w:] Career Development and Counseling. Putting Theory and Research to Work, red. S.D. Brown, R.W. Lent, John Wiley, New York 2005. 
Savicas M.L., Career construction: A developmental theory of vocational behavior, [w:] Career choice and development (4th ed.) red. D. Brown i in., Jossey - Bass, San Francisco CA 2002.

Savickas M.L., The Theory and practice of career construction, [w:] Career Development and Counseling. Putting Theory and Research to Work, Wiley, New York 2005.

Savicas M.L., Life Design: A Pardigm for Career Intervention in the 21 Century, Journal of Counseling and Development, Issue 1, January 2012, 90.

Savicas M.L., Lent R.W. (red.), Convergence in career development theories, CPP Books, Paolo Alto 1994.

Savickas M.L., Nota L., Rossier J., Dauwalder J., Duarte M.E., Guichard J., Van Vianen A.E.M., Life designing: a paradigm for career construction in $21^{\text {st }}$ century, Journal of Vocational Behavior, 2011, 75.

Siarkiewicz E., Przesłonięte obszary poradnictwa. Realia - iluzje - ambiwalencje, Wydawnictwo UZ, Zielona Góra 2010.

Solarczyk-Ambrozik E., Społeczno-ekonomiczne wyznaczniki zapotrzebowania na doradztwo zawodowe, Studia Edukacyjne, 2008, 7.

Solarczyk-Ambrozik E., Uczenie się przez całe życie jako rzeczywistość edukacyjna. Dyskurs catożyciowego uczenia się w tle zmian społeczno-ekonomicznych, [w:] Całożyciowe uczenie sie jako wyzwanie dla teorii i praktyki edukacyjnej, red. E. Solarczyk-Ambrozik, Wydawnictwo Naukowe UAM, Poznań 2013.

Sullivan S.E., The Changing Nature of Careers: A Review and Research Agenda, Journal of Management, 1999, 25, 3.

Wojtasik B., Doradca zawodu. Studium teoretyczne z zakresu poradoznawstwa, Wydawnictwo UWr, Wrocław 1994.

Wojtasik B., Refleksyjne konstruowanie kariery życiowej w ponowoczesnej codzienności, Człowiek - Teraźniejszość - Edukacja, 2003, numer specjalny.

Zunker V.G., Career Counseling: Applied Concepts of Life Planning, Brooks/Cole - Thomson Learning, 2002. 
